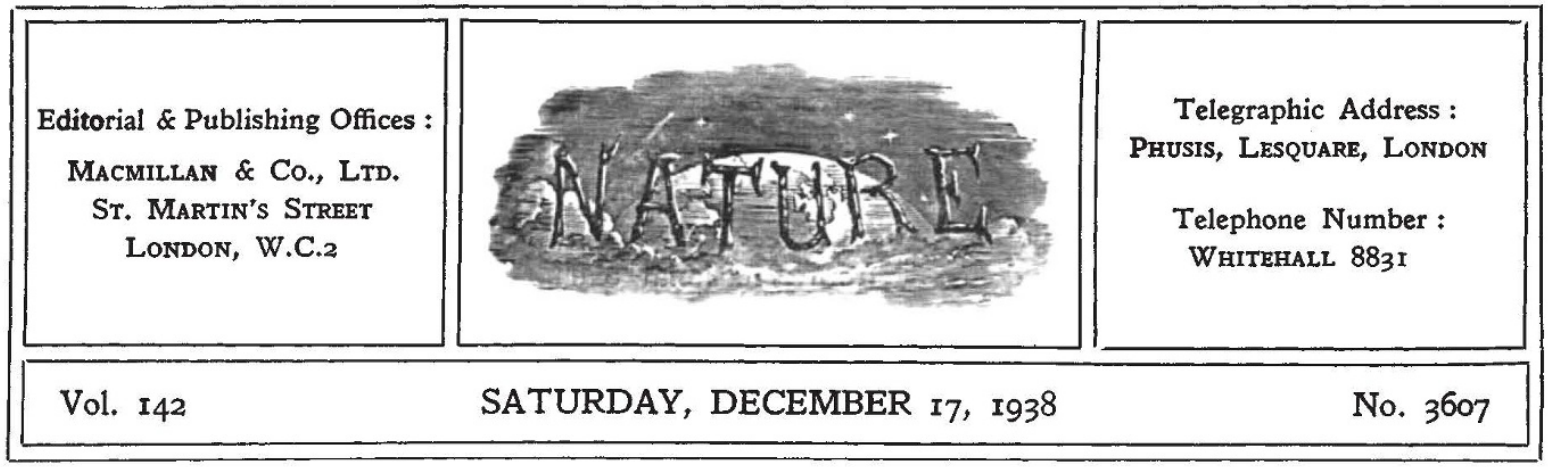

\title{
Science and Learning in Distress
}

$I^{N}$ the early summer of 1933, the Academic Assistance Council was founded, under the presidency of Lord Rutherford and with the active support of many distinguished men of science and other scholars, to find places in the fabric of world science and world scholarship for men and women driven from their countries and their work for racial, religious or political reasons. Such persecution was not new, even in the very recent past : it had happened again and again in Russia and was still happening: but the scale of its application in Germany and the distinction of its victims demanded immediate help. The Academic Assistance Council had no partisan, political or national bias. Indiscriminate relief was to be no part of its work. Its purpose was to act as a link between the scientific workers and other scholars displaced and the universities and research institutions of the world, so that their exceptional abilities exceptionally trained-to quote the noble declaration of the Council's founders-should not be lost.

It was hoped that the emergency would pass, but as the years went on, intolerance and persecution grew; no end was in sight. The Academic Assistance Council took permanent shape therefore as the Society for the Protection of Science and Learning: its wider purpose was now to act as a clearing house of information and advice to exiled scholars, and to persons, institutions and departments desiring to help them; its narrower purpose-within the limits of its resources-to offer temporary maintenance grants and other aids to re-establishment. The spread of 'racial' doctrine to Italy, the consequences in Austria and Czechoslovakia of the political events of 1938 and their reactions in neighbouring countries, the continuation of civil war in Spain, the extreme xenophobia of the U.S.S.R., and recent events in Germany, all these have added to the need, for information and advice on one hand, for direct assistance on the other. When a ship is in distress no sailor, and few landsmen, will not want to go to its help.

The Society has just issued its annual report, from which it appears that a widespread appeal is shortly to be issued : for funds on one hand ; for interest and sympathy, through membership, on the other. The problem has been complicated and enlarged by the events of 1938 , but the Society has not turned aside from its original purpose and principles. It exists, not to advertise a particular point of view, but to do an honest job of work in seeing that ability and experience in science and scholarship are not wasted. It does not, it cannot, disregard human values ; but its charity is devoted to those who can contribute to the common stock of learning. It stands for the brotherhood of scientific endeavour, regardless of race and creed and politics : and it stands for it, not by passing pious resolutions or by putting out disguised political propaganda, but by trying to help colleagues in their need. Foreign scientific workers are found work which restores their self-respect and makes others realize their value in their common task; so that, not seldom, they become self-supporting. From the start, however, the Society has done its best to avoid any unfair competition of exiled scientific workers and other scholars with those in the countries where they are seeking refuge, and has realized, and urged, that in the long run such competition is as little in 
the interest of the exiles as in that of scientific workers as a whole.

The Society must maintain its authority and integrity in the face of its increasing task. In Germany alone, fourteen hundred university teachers and research workers have been displaced, many of them among the most distinguished in the world; not merely debarred from teaching and research, they are not allowed to make a living at all. More than four hundred Austrian men of science and other students have been displaced, and of these only about a hundred have been able to leave the country. The full effects of the 'racial' policy in Italy and of the partition of Czechoslovakia have yet to be felt; Spain, from which scholars of both parties have been helped, is still no place for tolerant, sensitive academic people; and the U.S.S.R. has disappointed our hopes by turning out those who originally found work and refuge there.

Caution in the circumstances must often seem intolerable to humane men, but the Society's stringent caution in accepting responsibility bears fruit. Work has been found permanently for about 550 scholars in thirty-eight different countries, from Australia to Venezuela; for about 330 temporarily in twenty-five countries. Turkey, which is building a new civilization, has welcomed numbers of the displaced university men.

In November 1937, the Society called an informal conference at Oxford of representatives of European universities, and the ideal of an international exchange for information and employment came nearer to realization. The Society's register of exiled scholars is now unique, authoritative and international. Any academic or research institution can have the benefit of its records of those "exceptional abilities exceptionally trained", lost to their own countries, but not, if the Society can prevent it, to the service of knowledge anywhere else in the world.

Funds and interest are, however, an imperative need ; first, for the work of administration, information and advice; secondly, for direct help in human emergency. It is to be hoped that the wider educated public, particularly in the Englishspeaking countries, will respond generously to the appeal for support which the Society is making, and come to the help of science and learning in distress.

\section{Serialism and Immortality}

The New Immortality

By J. W. Dunne. Pp. 157. (London: Faber and Faber, Ltd., 1938.) $3 s .6 d$. net. HIS little book is intended to supply the
general reader with a more or less popular account of the theories about time and the self which Mr. Dunne has developed in considerable detail in his previous works, "An Experiment with Time" and "The Serial Universe". Mr. Dunne thinks that these theories are entailed by certain quite general facts about time and change, on one hand, and about self-consciousness on the other. The former reduce to the linguistic fact that we talk of future events as 'becoming real' or 'coming into existence', of past events as having 'ceased to be real' or having 'passed out of existence', and so on. The latter reduce to the linguistic fact that each of us uses expressions like 'my self' and 'your self', which seem to imply, in the case of each of us, the existence of an owned self and an owning self and an ' $I$ ' which knows them both and sees that the one owns the other.
Mr. Dunne assimilates this latter distinction with another, about which he makes much ado. This is the distinction between a recording instrument, for example, a magnetometer; a body which influences it in virtue of one of its properties, for example, a magnet; and the reading which the instrument records when thus influenced. $\mathrm{Mr}$. Dunne thinks that we are liable to confuse the reading of the instrument with the agent which causes the instrument to record this reading; and that many important consequences follow, on which the distinction throws a flood of light. I find it hard to believe that anyone except an extremely eminent mathematical physicist engaged in writing extremely bad philosophy ever would make such a gross mistake.

Taking these linguistic expressions literally and seriously, Mr. Dunne quite correctly infers that he is committed to an endless series of 'times' and an endless series of 'observers'. He also infers that each term in the series of 'times' reduces all the previous terms to additional dimensions of space. Time would be the last term of a series which, from the nature of the case, would have no 